\title{
Effects of a High Potassium Diet on Electrical Properties of Cortical Collecting Ducts from Adrenalectomized Rabbits
}

\author{
S. Muto, S. Sansom, and G. Giebisch \\ Department of Physiology, Yale University School of Medicine, New Haven, Connecticut 06510
}

\begin{abstract}
The cortical collecting tubule is one of the main nephron sites where mineralocorticoids and a high potassium diet modulate sodium $(\mathrm{Na})$ and potassium $(K)$ transport. In this study we explored the steroid-independent effects of a high $K$ diet on the electrical transport properties of the isolated rabbit cortical collecting tubule principal cells. The electrophysiological analysis included transepithelial and single-cell potential measurements and equivalent circuit analysis. Rabbits were adrenalectomized (ADX) and received either a control diet (300 meq $\mathrm{K} / \mathrm{kg}$ diet) or a high $\mathrm{K}$ diet $(600 \mathrm{meq} / \mathrm{kg}$ diet) for $10 \mathrm{~d}$ before the experiment. The mean plasma $K$ of $A D X$ control animals was $6.9 \mathrm{mM}$, that of ADX animals on the high $\mathrm{K}$ diet $8.3 \mathrm{mM}$. The transepithelial potential difference was significantly elevated in the high $K$ group ( $-3.5 \mathrm{mV}$, lumen negative), compared with ADX controls $(-1.4 \mathrm{mV})$. The basolateral membrane potential in high $\mathrm{K}$ animals was also significantly elevated $(-73 \mathrm{mV}$, cell negative, compared with $-63 \mathrm{mV}$ in controls). Estimates of the apical membrane partial $\mathrm{Na}$ and $\mathrm{K}$ conductances ( $G_{\mathrm{Na}}^{\mathrm{a}}$ and $G_{\mathrm{K}}^{\mathrm{a}}$ ) and of ion currents ( $I_{\mathrm{Na}}^{\mathrm{a}}$ and $I_{\mathrm{K}}^{\mathrm{a}}$ ) also demonstrated stimulation by the high $K$ diet. In the high $K$ group, both $G_{\mathrm{Na}}^{\mathrm{a}}$ and $G_{\mathrm{K}}^{2}\left(0.56\right.$ and $\left.2.67 \mathrm{mS} \cdot \mathrm{cm}^{-2}\right)$ were higher than control values $\left(0.27\right.$ and $\left.1.17 \mathrm{mS} \cdot \mathrm{cm}^{-2}\right) . I_{\mathrm{Na}}^{\mathrm{a}}$ and $I_{K}^{\mathrm{a}}$ were also higher in high $\mathrm{K}$ animals $\left(47.8\right.$ and $\left.-26.2 \mu \mathrm{A} \cdot \mathrm{cm}^{-2}\right)$ compared with control animals $\left(22.4\right.$ and $\left.-11.6 \mu \mathrm{A} \cdot \mathrm{cm}^{-2}\right)$. Thus, a high $K$ intake per se can induce electrophysiological changes consistent with stimulation of $\mathrm{Na}$ reabsorption and $\mathrm{K}$ secretion.
\end{abstract}

\section{Introduction}

Microperfusion studies (1-3), electrophysiological experiments (4-7), and morphological (8-10) and enzyme analyses (11-16) have identified the cortical collecting tubule of the rabbit as a key nephron site of regulation of $\mathrm{Na}$ and $\mathrm{K}$ transport. A high $\mathrm{K}$ intake is a particularly powerful stimulus of ion transport across the collecting tubule epithelium, activating aldosterone release, $\mathrm{Na}$ reabsorption and $\mathrm{K}$ secretion, basolateral membrane amplification, and ATPase expression $(8,9)$. Similar functional and morphological changes have also been

Portions of this work have been published in abstract form (1986. Kidney Int. 29:403).

Dr. Muto's present address is Department of Cardiology, Jichi Medical School, Minamiwachi, Tochigi 329-04, Japan. Address correspondence and reprint requests to Dr. Sansom.

Received for publication 9 April 1987 and in revised form 9 September 1987.

J. Clin. Invest.

(c) The American Society for Clinical Investigation, Inc.

0021-9738/88/02/0376/05 \$2.00

Volume 81, February 1988, 376-380 observed in initial collecting tubules of the rat nephron $(17,18)$.

There is also evidence that $\mathrm{K}$ secretion across the cortical collecting tubule can be modulated by a high $\mathrm{K}$ intake independently of aldosterone. For instance, imposition of an acute $(19,20)$ or chronic $(21) \mathrm{K}$ load in adrenalectomized (ADX) animals, in which steroid levels were "clamped" to low levels, still induced significant kaliuresis. Such K loads also elevated collecting tubule ATPase (22) and induced basolateral membrane amplification (18).

Wingo et al. (21) were the first to show that transition from a low to a high $\mathrm{K}$ diet stimulated active $\mathrm{K}$ secretion in the cortical collecting tubule in ADX rabbits (21). The present study explores the steroid-independent mechanism by which a high $\mathrm{K}$ diet in ADX rabbits stimulates $\mathrm{Na}$ and $\mathrm{K}$ transport. Experiments were carried out on electrically identified principal cells (23) and we observed electrophysiological changes consistent with activation of basolateral $\mathrm{Na}-\mathrm{K}$ exchange as well as a significant increase of apical $\mathrm{Na}$ and $\mathrm{K}$ conductances.

\section{Methods}

The experiments were carried out on two groups of New Zealand white female rabbits weighing between 1 and $3 \mathrm{~kg}$. All animals were ADX by methods previously described (23). After surgery, the animals received $0.5 \mathrm{mg} / \mathrm{kg}$ dexamethasone per day for $2 \mathrm{~d}$ and $0.9 \% \mathrm{NaCl}$ as drinking solution. Rabbits were maintained for $10 \mathrm{~d}$ on a diet either containing $\sim 300 \mathrm{meq} \mathrm{K} / \mathrm{kg}$ diet (rabbit Chow, Ralston Purina Co., St. Louis, MO) or a special high $\mathrm{K}$ diet ( $600 \mathrm{meq} \mathrm{K} / \mathrm{kg}$ diet, Teklad, Madison, WI). A difference in these two diets was that the high $\mathrm{K}$ diet contained $15 \%$ sucrose. We found that ADX rabbits failed to consume a high $\mathrm{K}$ diet unless sucrose was added to the mixture. The $\mathrm{Na}$ content was slightly less in control $(0.32 \%)$ than in the high $\mathrm{K}$ diet $(0.43 \%)$. Consumption of rabbit Chow was monitored for all rabbits and averaged close to $40 \mathrm{~g} / \mathrm{d}$ in both groups. Rabbits that consumed $<20 \mathrm{~g} / \mathrm{d}$ were usually too weak and were not included in the study. Blood samples were drawn at the time of the experiments and analyzed for $\mathrm{Na}, \mathrm{K}$, and aldosterone, the latter being measured by radioimmunoassay (Diagnostic Products Corp., Los Angeles, CA).

Cortical collecting tubules were isolated and perfused at $37^{\circ} \mathrm{C}$ from 30 to $90 \mathrm{~min}$ after sacrifice by methods described in detail in other articles $(24,25)$. High flow rates were maintained through the isolated tubules $(15 \mathrm{nl} / \mathrm{min})$ and through the bath chamber $(15 \mathrm{ml} / \mathrm{min})$. All perfusion solutions contained the following solutes (mM): $141 \mathrm{Na}, 5$ $\mathrm{K}, 1 \mathrm{Ca}, 1 \mathrm{Mg}, 144 \mathrm{Cl}, 0.5 \mathrm{HPO}_{4}$, and 2.5 Pipes buffer. The bath solution was identical except that $5.6 \mathrm{mM}$ glucose was added. Some tubule perfusion solutions contained $\mathrm{BaCl}(5 \mathrm{mM})$ or amiloride $(50 \mu \mathrm{M})$.

Electrical measurements such as transepithelial and basolateral cell membrane potential differences and fractional resistance measurements, as well as the equivalent circuit analysis were the same as described in two previous articles $(6,23)$. Cell impalements in this study were limited to principal cells that had been characterized in previous studies by other investigators $(21,26)$ as well as by us $(23)$ by

1. Abbreviation used in this paper: ADX, adrenalectomized. 
relatively low apical membrane fractional resistances $\left(\mathrm{fR}^{\mathrm{a}}\right)$, higher basolateral membrane potentials $\left(-V^{\text {b}}\right)$, and significant barium and amiloride-sensitive apical membrane conductive pathways (23).

The principal cell model used in our analysis consists of an apical cell membrane with an amiloride-sensitive $\mathrm{Na}$ and a barium-sensitive $\mathrm{K}$ conductive pathway.

The apical, basolateral, and tight junction membrane conductances $\left(G^{\mathrm{a}}, G^{\mathrm{b}}\right.$, and $G^{\mathrm{t}}$, respectively) were estimated using the following equations:

$\Delta G^{\mathrm{te}}=\left(1-\Delta \mathrm{fR}^{\mathrm{a}}\right) G^{\mathrm{b}}+G^{\mathrm{tj}}$

$\mathrm{fR}^{\mathrm{a}}=G^{\mathrm{b}} /\left(G^{\mathrm{a}}+G^{\mathrm{b}}\right)$,

where $\Delta G^{\mathrm{te}}$ and $\Delta \mathrm{fR}^{\mathrm{a}}$ are the respective changes in transepithelial conductance and apical membrane fractional resistance upon the addition of $5 \mathrm{mM}$ luminal barium.

The partial apical membrane Na conductance $\left(G_{\mathrm{Na}}^{\mathrm{a}}\right)$ and $\mathrm{K}$ conductance $\left(G_{\mathrm{K}}^{\mathrm{a}}\right)$ are the amiloride and barium-sensitive apical membrane conductances, respectively, and are expressed as millisiemens per square centimeter.

The basolateral membrane contains a sodium-potassium exchange pump and potassium and chloride conductances. The net current $\left(I_{\text {net }}^{\mathrm{a}}\right)$ is given as the sum of the partial apical membrane $\mathrm{Na}$ current $\left(I_{\mathrm{Na}}\right)$ and $\mathrm{K}$ current $\left(I_{\mathrm{K}}^{\mathrm{a}}\right)$ by the following expression:

$I_{\text {net }}^{\mathrm{a}}=I_{\mathrm{Na}}^{\mathrm{a}}+I_{\mathrm{K}}^{\mathrm{a}}$.

$I_{\mathrm{Na}}^{\mathrm{a}}$ and $I_{\mathrm{K}}^{\mathrm{a}}$ are:

$I_{\mathrm{Na}}^{\mathrm{a}}=\left(V^{\mathrm{a}}-E_{\mathrm{Na}}^{\mathrm{a}}\right) G_{\mathrm{Na}}^{\mathrm{a}}$,

and

$I_{\mathrm{K}}^{\mathrm{a}}=\left(V^{\mathrm{a}}-E_{\mathrm{K}}^{\mathrm{a}}\right) G_{\mathrm{K}}^{\mathrm{a}}$,

where $V^{\text {a }}$, the apical cell membrane potential, was derived from the difference between the transepithelial potential $\left(V^{r^{e}}\right)$ and the basolateral cell membrane potential $\left(V^{b}\right)$, where $E_{\mathrm{Na}}^{\mathrm{a}}$ and $E_{\mathrm{K}}^{\mathrm{a}}$ are the respective electromotive forces for $\mathrm{Na}$ and $\mathrm{K}$ and are expressed as millivolts. These methods have been described in detail (6).

There was only one reported observation (with respective equivalent circuit values) from each tubule and one tubule per rabbit. When more than one successful impalement was done in one tubule, the values were averaged. Blood samples for analyzing $\mathrm{Na}, \mathrm{K}$, and aldosterone were obtained from six of seven control and five of six rabbits on the high $\mathrm{K}$ diet.

Results are presented as means \pm SEM. Differences between groups were determined by the $t$ test for unpaired data.

\section{Results}

Table I summarizes plasma electrolyte and aldosterone levels in the ADX controls and ADX + high $\mathrm{K}$ diet animals. Both groups had a moderately reduced plasma $\mathrm{Na}$ level. The plasma $\mathrm{K}$ level in the animals receiving a high $\mathrm{K}$ diet was significantly elevated compared with that in ADX animals receiving the

Table I. Plasma Na, K, and Aldosterone Concentrations

\begin{tabular}{llll}
\hline Group & Aldosterone & $\mathrm{Na}$ & $\mathrm{K}$ \\
\hline & $p g / m l$ & meq/liter & meq/liter \\
$\mathrm{ADX}(n=6)$ & $4.0 \pm 4.0$ & $136.0 \pm 2.4$ & $6.9 \pm 0.4$ \\
$\begin{array}{c}\mathrm{ADX}+\text { high K } \\
(n=5)\end{array}$ & $\mathrm{ND}$ & $133.8 \pm 4.2$ & $8.3 \pm 0.2^{*}$
\end{tabular}

Values are means \pm SEM. ND, not determined.

$* P<0.05$.

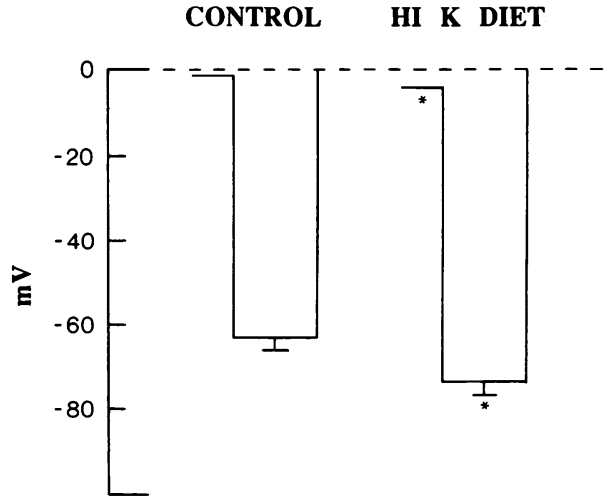

Figure 1. Potential profiles of cortical collecting tubule principal cells of control and high $\mathrm{K}$ diet groups. Error bars are $-\mathrm{SEM},{ }^{*} P<0.05$. The top of each profile is ground or zero potential. $V^{\text {re }}$ is represented as the left line of each profile and $V^{b}$ is the bottom line and $V^{a}$ is the difference between $V^{t e}$ and $V^{b}$.

control diet. Importantly, neither group had detectable levels of plasma aldosterone.

Fig. 1 provides information on the electrical potential profile in the two groups of cortical collecting tubules. The transepithelial potential difference, $V^{t e}$, of control ADX tubules was low $(-1.4 \pm 0.5 \mathrm{mV})$ compared with previously reported values for cortical collecting tubules from adrenal-intact animals (22). Our data confirm the results of Wingo et al. (21), who also observed a reduction of $-V^{t e}$ in cortical collecting tubules from ADX rabbits (21). Compared with $\mathrm{ADX}$ rabbits, $-V^{t e}$ was higher $(-3.9 \pm 0.9 \mathrm{mV})$ in tubules from ADX rabbits receiving a high $\mathrm{K}$ diet.

Fig. 1 also provides information on cell potentials in the two groups of tubules. The basolateral membrane potential $\left(-V^{b}\right)$ of ADX animals was smaller $(-63.0 \pm 3 \mathrm{mV})$ compared with reported values for adrenal-intact tubules $(-82 \mathrm{mV} \mathrm{[23]),}$ and significantly elevated $(-73 \pm 3 \mathrm{mV})$ when a high $\mathrm{K}$ diet was given.

Table II provides a summary of the barrier conductances of the perfused cortical collecting tubules. The values of fractional resistance $\left(\mathrm{fR}^{\mathrm{a}}\right)$, the transepithelial conductance $\left(G^{\mathrm{te}}\right)$, the basolateral membrane conductance $\left(G^{\mathrm{b}}\right)$, and the intercellular shunt conductance $\left(G^{\mathrm{t} j}\right)$ were not different in the control $\mathrm{ADX}$ and $\mathrm{ADX}+$ high $\mathrm{K}$ diet groups. However, the apical membrane conductance, $G^{\mathrm{a}}$, was significantly higher in the group of cortical collecting tubules harvested from ADX rabbits receiving a high $\mathrm{K}$ diet. The basolateral membrane conductance, $G^{\mathrm{b}}$, was higher in the collecting ducts from $\mathrm{K}$ -

Table II. Effects of High $K$ Diet on $f^{a}$ and Barrier Conductances

\begin{tabular}{|c|c|c|c|c|c|}
\hline & $\mathbf{f R}^{*}$ & $G^{*}$ & $G^{\wedge}$ & $G^{\mathbf{b}}$ & $G^{\mathbf{j}}$ \\
\hline & $\mathrm{mS} \cdot \mathrm{cm}^{-2}$ & $\mathrm{mS} \cdot \mathrm{cm}^{-2}$ & $m S \cdot \mathrm{cm}^{-2}$ & $\mathrm{mS} \cdot \mathrm{cm}^{-2}$ & $m S \cdot \mathrm{cm}^{-2}$ \\
\hline $\operatorname{ADX}(n=7)$ & $0.63 \pm 0.06$ & $9.8 \pm 1.3$ & $1.5 \pm 0.3$ & $3.5 \pm 1.0$ & $8.8 \pm 1.2$ \\
\hline $\begin{array}{l}\text { ADX + high K } \\
(n=6)\end{array}$ & $0.67 \pm 0.06$ & $9.3 \pm 0.9$ & $3.4 \pm 0.5$ & $9.1 \pm 3.4$ & $7.0 \pm 0.9$ \\
\hline$P$ & NS & NS & $<0.01$ & NS & NS \\
\hline
\end{tabular}

Values are means \pm SEM. 

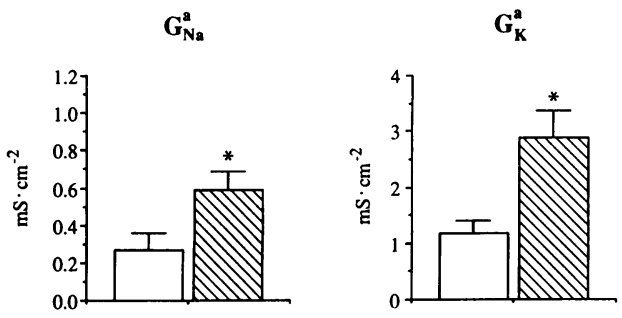

Figure 2. Effects of high $\mathrm{K}$ diet on apical membrane $\mathrm{Na}$ and $\mathrm{K}$ conductances $\left(G_{\mathrm{Na}}^{\mathrm{a}}\right.$ and $G_{\mathrm{K}}^{\mathrm{a}}$, respectively). Error bars are $+\mathrm{SEM},{ }^{*} P$ $<0.05$.

treated rabbits but the difference was not statistically significant, possibly because of the variability of $G^{\mathrm{b}}$ values due to the variable chloride conductance typically observed in this membrane (27).

Fig. 2 graphically summarizes estimated mean values of apical membrane $\mathrm{Na}$ and $\mathrm{K}$ conductances. $G_{\mathrm{Na}}^{\mathrm{a}}$ increased from $0.27 \pm 0.09 \mathrm{mS} / \mathrm{cm}^{2}$ in control to $0.56 \pm 0.09 \mathrm{mS} / \mathrm{cm}^{2}$ in the high $\mathrm{K}$ diet group. $G_{\mathrm{K}}^{\mathrm{a}}$, which was $1.17 \pm 0.24 \mathrm{mS} / \mathrm{cm}^{2}$ in controls, increased to $2.67 \pm 0.47$.

Fig. 3 shows the values of the partial ionic currents. Both $I_{\mathrm{Na}}^{\mathrm{a}}$ and $-I_{\mathrm{K}}^{\mathrm{a}}$ increased from $22.4 \pm 5.2$ and $11.6 \pm 2.4 \mu \mathrm{A} / \mathrm{cm}^{2}$, to $47.8 \pm 7.8$ and $26.2 \pm 3.4 \mu \mathrm{A} / \mathrm{cm}^{2}$, respectively.

The increases in the apical conductances and currents of $\mathrm{Na}$ and $\mathrm{K}$ are consistent with the observation that a high $\mathrm{K}$ diet stimulates $\mathrm{Na}$ and $\mathrm{K}$ transport independent of adrenal steroids (20).

\section{Discussion}

Our electrophysiological experiments confirm and extend the growing body of evidence that changes in $\mathrm{K}$ balance activate $\mathrm{Na}$ and $\mathrm{K}$ transport across cortical collecting tubules independent of adrenal steroids. We observed that the administration of a high $\mathrm{K}$ diet to ADX rabbits brings about changes in the electrophysiological behavior of collecting duct cells quite similar to those of mineralocorticoids such as aldosterone and deoxycorticosterone acetate (DOCA) $(5,6,28)$. Thus, the most important findings of our study were the $\mathrm{K}$-induced increase in the apical conductances of $\mathrm{Na}$ and $\mathrm{K}$ as well as the significant increase in the basolateral membrane potential, changes that led to a doubling of the estimated $\mathrm{Na}$ and $\mathrm{K}$ currents. A summary of these electrophysiological changes in control ADX and ADX K-loaded animals is presented in Fig. 4.

Two cell types have been identified in cortical collecting tubules with several methods allowing a distinction to be made between principal and intercalated cells $(11,23,26,29)$. The
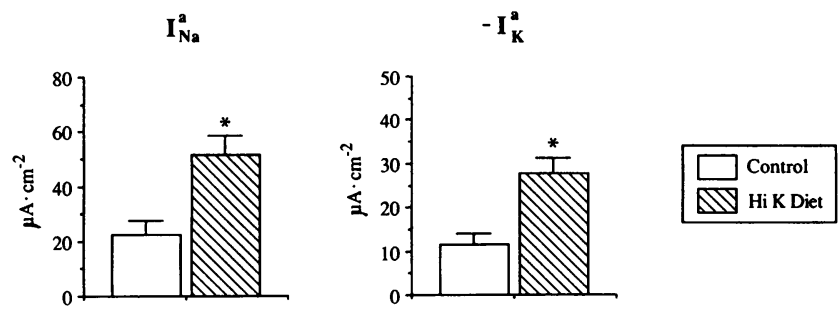

Figure 3. Effects of high $\mathrm{K}$ diet on apical membrane $\mathrm{Na}$ and $\mathrm{K}$ currents $\left(I_{\mathrm{Na}}^{\mathrm{a}}\right.$ and $-I_{\mathrm{K}}^{\mathrm{a}}$, respectively). Error bars are $+\mathrm{SEM},{ }^{*} P<0.05$. present study describes changes in the majority cell type, the principal cell, distinguished by a relatively low fractional resistance $\left(\mathrm{fR}^{\mathrm{a}}\right)$, and significant amiloride- and barium-sensitive ion conductances in the apical cell membrane (23). It is the latter cell type that has been identified as the site of mineralocorticoid action in the cortical collecting tubule $(9,23,29)$. We conclude from the present study that a high $\mathrm{K}$ intake also modulates $\mathrm{Na}$ and $\mathrm{K}$ transport in principal cells.

Our results of both apical and basolateral transport stimulation by high $\mathrm{K}$, independent of aldosterone activation that would normally occur after $\mathrm{K}$ loading, is not unexpected. First, Wingo et al. (21) have shown that a high $\mathrm{K}$ diet in ADX rabbits increases net $\mathrm{Na}$ and $\mathrm{K}$ transport in the cortical collecting tubule. Recent studies have also shown that a high $\mathrm{K}$ diet in ADX rabbits significantly increases the ATPase activity in single cortical collecting tubules over a similar time course as in our studies (22). ${ }^{2}$ An increase of the basolateral membrane area of initial cortical collecting tubules was also observed in ADX rats receiving high $\mathrm{K}$ (17). An increase in membrane ATPase and basolateral membrane amplification have been previously observed in animals with intact adrenals receiving $K(9,10,30-32)$ and in animals on a constant $K$ diet in which the mineralocorticoid level was chronically elevated by minipump infusion (18). Inasmuch as an increased ATP content and membrane amplification were associated with transport stimulation, similar observation in ADX animals receiving high $\mathrm{K}$, referred to above, support the view of transport stimulation independent of steroids.

The aldosterone-independent mechanism by which a high $\mathrm{K}$ intake stimulates not only potassium but also sodium transport, is not clear but two possibilities should be considered. The first involves stimulation of basolateral $\mathrm{K}$ uptake by active $\mathrm{Na}-\mathrm{K}$ exchange due to the elevated plasma $\mathrm{K}$ in ADX animals receiving a high $\mathrm{K}$ load. The resultant elevated turnover of the pump would then induce a secondary increase in both apical membrane $\mathrm{Na}$ and $\mathrm{K}$ conductance. Although the mechanism by which basolateral pump stimulation modulates apical ion conductances is presently not known, we $(23,32)$ and others (33) have observed a tight coupling between active basolateral pump turnover and $\mathrm{Na}$ and $\mathrm{K}$ conductances. It is conceivable that cell ion activity changes involving $\mathrm{K}$ may mediate the apical conductance changes independent of steroids.

A second mechanism may be changes in vasopressin levels due to $\mathrm{K}$ loading. It has recently been reported that a high dietary $\mathrm{K}$ intake is associated with elevated plasma vasopressin (34). Relevant within this context is the observation of Reif et al. (35) in isolated rat collecting ducts that vasopressin stimulates the apical $\mathrm{Na}$ conductance. An increase in sodium entry into the cell, pump stimulation and increased $\mathrm{K}$ uptake is a possible sequence of events.

\footnotetext{
2. A comparison of the transport stimulation in the present study with measurements of cortical collecting tubule ATPase by Garg and Narang (22) is of interest. Assuming a Na-K exchange ratio of 3:2 in both groups of animals, we can estimate a pump current (equal to one-third $I_{\mathrm{Na}}^{\mathrm{a}}$ ) of 7.5 and $15.9 \mu \mathrm{A} \cdot \mathrm{cm}^{-2}$ in control ADX, and ADX + high $\mathrm{K}$ diet groups, respectively. This relative increase compares well with measurements of 16 and $31 \mathrm{pmol} \cdot \mathrm{mm}^{-1} \cdot \mathrm{min}^{-1}$ in similarly treated rabbits in the study of Garg and Narang in which the respective diets contained 300 and $700 \mathrm{meq} / \mathrm{kg}$ of potassium. Thus, in both our and their studies, sodium pump activity approximately doubled with the high $\mathrm{K}$ intake.
} 


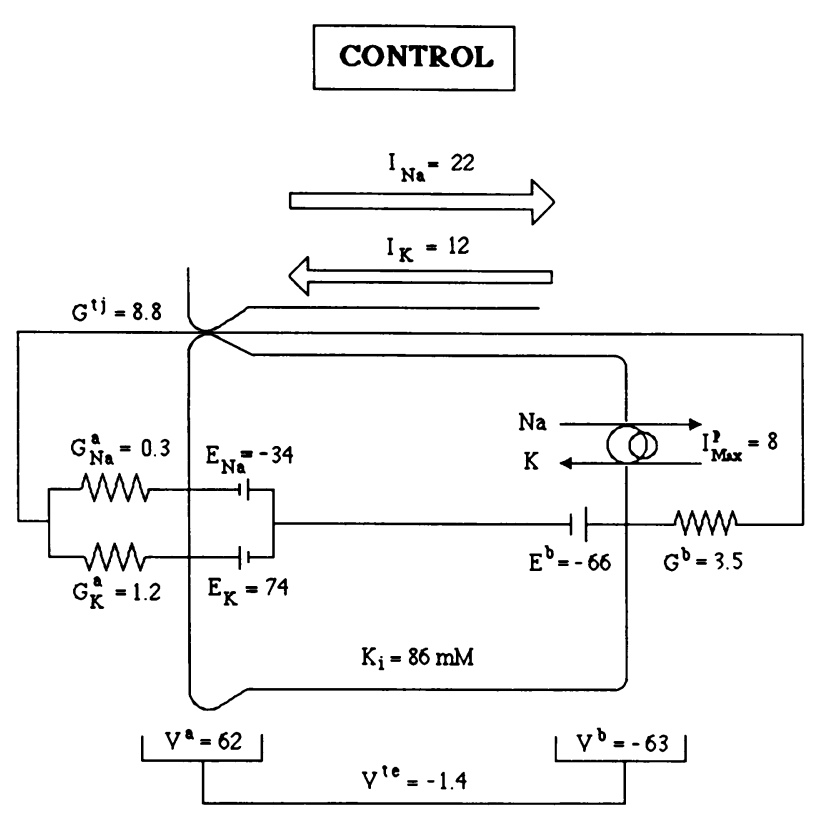

Figure 4. Comparison of equivalent circuit parameters of cortical collecting tubule principal cells from ADX rabbits on either a control or high $\mathrm{K}$ diet. The equivalent electromotive force of the basolateral membrane $\left(E^{\mathrm{b}}\right)$ includes $\mathrm{Cl}$ and $\mathrm{K}$ conductive pathways. All membrane potentials and electromotive forces, $V^{\mathrm{re}}, V^{\mathrm{a}}, V^{\mathrm{b}}, E_{\mathrm{Na}}^{\mathrm{a}}, E_{\mathrm{K}}^{\mathrm{a}}$,

The possibility that an electrically neutral transport mechanism of $\mathrm{K}$ secretion was activated in the present experiments by the high $\mathrm{K}$ diet cannot be excluded (36). However, we have previously shown that the transport rates of $\mathrm{Na}$ and $\mathrm{K}$, estimated electrically and chemically, are not different in collecting tubules of both adrenal intact and ADX rabbits. This view is also supported by the data summarized in Table III that compares our results with those of Wingo et al. (21) who measured $\mathrm{Na}$ and $\mathrm{K}$ fluxes chemically. It is apparent that rabbits on a diet of $300 \mathrm{meq} / \mathrm{kg}$ have very comparable sodium and potassium transport rates: chemically measured fluxes were 6.2 and $-5.3 \mathrm{peq} \cdot \mathrm{mm}^{-1} \cdot \mathrm{s}^{-1}$, compared with electrically measured fluxes of 8.8 and $-4.6 \mathrm{peq} \cdot \mathrm{mm}^{-1} \cdot \mathrm{s}^{-1}$, respectively. Inspection of Table III further underscores the clear relationship between $\mathrm{K}$ content of the diet and transport rates, independent of whether transport was estimated chemically or electrically.

Whatever the mechanism(s) of nonsteroid-related trans-

Table III. Comparison of Flux Study by Wingo et al. (21) and Electrical Study by Muto (Present Study)

\begin{tabular}{|c|c|c|c|c|c|c|}
\hline \multirow[b]{2}{*}{ Diet } & \multicolumn{2}{|c|}{ Plasma K } & \multicolumn{2}{|l|}{$J_{\mathrm{Na}}$} & \multicolumn{2}{|l|}{$J_{\mathbf{K}}$} \\
\hline & Wingo & Muto & Wingo & Muto & Wingo & Muto \\
\hline $\mathrm{meq} \mathrm{K} / \mathrm{kg}$ & \multicolumn{2}{|c|}{ meq/liter } & \multicolumn{4}{|c|}{$\mathrm{pmol} / \mathrm{mm}$ per min } \\
\hline 600 & & 8.3 & & 20.2 & & -10.9 \\
\hline 300 & 6.1 & 6.9 & 6.2 & 8.8 & -5.3 & -4.6 \\
\hline 3 & 2.0 & & 3.8 & & -2.0 & \\
\hline
\end{tabular}

In both studies, rabbits were ADX and maintained on diet for $10 \mathrm{~d}$ prior to the experiment. $J_{\mathrm{Na}}$ and $J_{\mathrm{K}}$ are corrected to net flux expressed as picomoles per millimeter tubule length per minute.

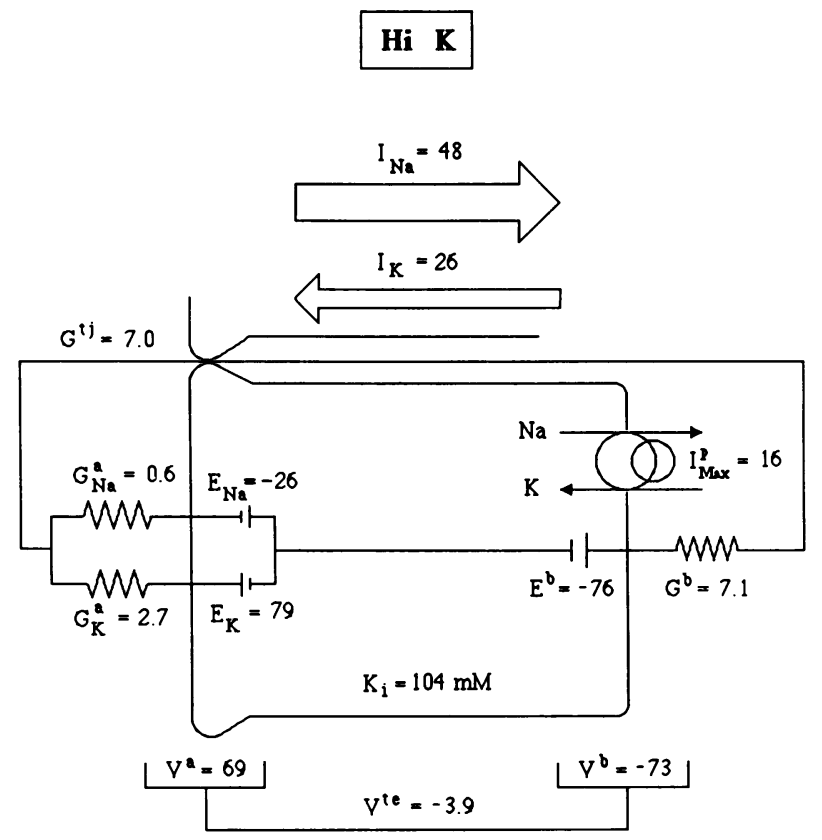

and $E^{\mathrm{b}}$ are in millivolts. $G_{\mathrm{Na}}^{\mathrm{a}}, G_{\mathrm{K}}^{\mathrm{a}}, G^{\mathrm{t}}$, and $G^{\mathrm{b}}$ are in millisiemens per square centimeter. $I_{\mathrm{Na}}$ and $I_{\mathrm{K}}$ are the transepithelial $\mathrm{Na}$ and $\mathrm{K}$ currents, respectively, and are in microamperes per square centimeter. For details see text.

port stimulation of the cortical collecting tubule by a high $\mathrm{K}$ intake, it should be noted that the observed transport rates of $\mathrm{Na}$ and $\mathrm{K}$ after $\mathrm{K}$ loading in ADX animals are considerably less than those in cortical collecting tubules from adrenal-intact rabbits receiving a $\mathrm{K}$ load $(1,3)$. Accordingly, an intact adrenal system is essential for the full adaptive transport response of cortical collecting ducts to $\mathrm{K}$ loads.

In conclusion, our studies have shown aldosterone-independent electrical effects of a high $\mathrm{K}$ load on the principal cell population of ADX rats. The changes involve a significant cell hyperpolarization and increased apical membrane conductances for $\mathrm{Na}$ and $\mathrm{K}$. These studies support and extend previous evidence that the principal cell of the cortical collecting duct is responsible for partial correction of hyperkalemia in adrenal-deficient states.

\section{Acknowledgments}

We are grateful to Dr. Harry Jacobson for information regarding the adrenalectomy procedure and to Dr. Lal Garg for information concerning specialized diet preparations for ADX rabbits.

This study was supported by grant AM-17433 from the National Institutes of Health. S. Muto was supported by a training grant from the Connecticut Heart Association. S. Sansom was supported by training grant AM-7259-09 from the National Institutes of Health.

\section{References}

1. O'Neil, R., and S. I. Helman. 1977. Transport characteristics of renal collecting tubules: influences of DOCA and diet. Am. J. Physiol. 239:F544-F558.

2. Stokes, J. B. 1981. Potassium secretion by the cortical collecting tubule: relation to sodium absorption, luminal sodium concentration, and transepithelial voltage. Am. J. Physiol. 241:F395-F402.

3. Schwartz, G. J., and M. B. Burg. 1978. Mineralocorticoid effects 
on cation transport by cortical collecting tubules in vitro. Am. J. Physiol. 235:F576-F585.

4. Koeppen, B. M., and G. Giebisch. 1983. Electrophysiology of mammalian renal tubules: influences from intracellular microelectrode studies. Annu. Rev. Physiol. 45:497-517.

5. Koeppen, B. M., B. Biagi, and G. Giebisch. 1983. Intracellular microelectrode characterization of the rabbit CCT. Am. J. Physiol. 244:F35-F47.

6. Sansom, S. C., and R. G. O’Neil. 1985. Mineralocorticoid regulation of apical cell membrane $\mathrm{Na}^{+}$and $\mathrm{K}^{+}$transport of the cortical collecting duct. Am. J. Physiol. 248:F858-F868.

7. Sansom, S. C., and R. G. O'Neil. 1986. Effects of mineralocorticoids on transport properties of the cortical collecting duct basolateral membrane. Am. J. Physiol. 251:F743-F757.

8. Stanton, B., A. Janzen, G. Klein-Robbenhaar, R. DeFronzo, G. Giebisch, and J. Wade. 1985. Ultrastructure of rat initial collecting tubule. Effect of adrenal corticosteroid treatment. J. Clin. Invest. 75:1327-1334.

9. Wade, J., R. O’Neil, J. Pryor, and E. Boulpaep. 1979. Modulation of cell membrane area in renal collecting tubules by corticosteroid hormones. J. Cell Biol. 81:439-445.

10. Kaissling, B., and M. LeHir. 1982. Distal tubular segments of the rabbit kidney after adaptation to altered Na- and K-intake. Cell Tissue Res. 224:469-492.

11. O'Neil, R. G., and R. A. Hayhurst. 1985. Functional differentiation of cell types of cortical collecting duct. Am. J. Physiol. 248:F449-F453.

12. Petty, K. J., J. P. Kokko, and D. Marver. 1981. Secondary effect of aldosterone on Na-K-ATPase activity in the rabbit cortical collecting tubule. J. Clin. Invest. 68:1514-1521.

13. Garg, L. C., M. A. Knepper, and M. B. Burg. 1981. Mineralocorticoid effects on Na-K-ATPase in individual nephron segments. Am. J. Physiol. 240:F536-F544.

14. Westenfelder, C., G. J. Arevalo, R. L. Baronowski, N. A. Kurtzman, and A. I. Katz. 1977. Relationship between mineralocorticoids and renal $\mathrm{Na}^{+} / \mathrm{K}^{+}$-ATPase: sodium reabsorption. Am. J. Physiol. 233:F593-F599.

15. Mujais, S. K., A. Chekai, W. J. Jones, J. P. Hayslett, and A. I. Katz. 1985. Modulation of renal sodium-potassium-adenosine triphosphatase by aldosterone. J. Clin. Invest. 76:170-176.

16. El Mernissi, G., and A. Doucet. 1984. Specific activity of Na-K-ATPase after adrenalectomy and hormone replacement along the rabbit nephron. Pflügers Arch. 402:258-263.

17. Hirsch, D., M. Kashgarian, E. L. Boulpaep, and J. P. Hayslett. 1984. Role of aldosterone in the mechanism of potassium adaptation in the initial collecting duct. Kidney Int. 26:798-807.

18. Stanton, B., L. Pan, H. Deetjen, V. Guckian, and G. Giebisch. 1987. Independent effects of aldosterone and potassium on induction of potassium adaptation in rat kidney. J. Clin. Invest. 79:198-206.

19. Field, M. J., B. A. Stanton, and G. H. Giebisch. 1984. Differential acute effects of aldosterone, dexamethasone, and hyperkalemia on distal tubular potassium secretion in the rat kidney. J. Clin. Invest. 74:1792-1802.
20. Stanton, B. A., and G. H. Giebisch. 1982. Potassium transport by the renal distal tubule: effects of potassium loading. Am. J. Physiol. 243:F487-493.

21. Wingo, C. S., D. W. Seldin, J. P. Kokko, and H. R. Jacobson. 1982. Dietary modulation of active potassium secretion in the cortical collecting tubule of adrenalectomized rabbits. J. Clin. Invest. 70:579586.

22. Garg, L., and N. Narang. 1985. Renal adaptation to potassium in the adrenalectomized rabbit. Role of distal tubular sodium-potassium adenosine triphosphatase. J. Clin. Invest. 76:1065-1070.

23. Muto, S., G. Giebisch, and S. Sansom. 1987. Effects of adrenalectomy on cortical collecting tubule: evidence for differential response of two cell types. Am. J. Physiol. 253:F242-F752.

24. Burg, M. B., M. Grantham, S. Abramov, and J. Orloff. 1966. Preparation and study of fragments of single rabbit nephrons. Am. J. Physiol. 210:1293-1298.

25. O'Neil, R. G., and S. C. Sansom. 1984. Characterization of apical cell membrane $\mathrm{Na}^{+}$and $\mathrm{K}^{+}$conductances of cortical collecting duct using microelectrode techniques. Am. J. Physiol. 247:F14-F24.

26. Schlatter, E., and J. A. Schafer. 1987. Electrophysiological studies in principal cells of rat cortical collecting tubules. ADH increases the apical membrane $\mathrm{Na}^{+}$-conductance. Pflügers Arch. 409:81-92.

27. Sansom, S. C., E. J. Weinman, and R. G. O’Neil. 1984. Microelectrode assessment of chloride-conductive properties of cortical collecting duct. Am. J. Physiol. 247:F291-F302.

28. Sansom, S. C., S. Muto, and G. Giebisch. 1986. Na-dependent effects of DOCA on cellular transport properties of CCDs from ADX rabbits. Am. J. Physiol. 253:F753-F759.

29. Dobyan, D. C., and R. E. Bulger. 1983. Renal carbonic anhydrase. Am. J. Physiol. 243:F311-F324.

30. O'Neil, R. G., and R. A. Hayhurst. 1985. Sodium-dependent modulation of the renal Na-K-ATPase: influence of mineralocorticoids on the cortical collecting duct. J. Membr. Biol. 85:169-179.

31. LeHir, M., B. Kaissling, and U. C. Dubach. 1982. Distal tubular segments of the rabbit kidney after adaptation to altered $\mathrm{Na}$ - and K-intake. Cell Tissue Res. 224:493-504.

32. Matsumura, Y., B. Cohen, W. B. Guggino, and G. Giebisch 1984. Regulation of the basolateral potassium conductance of the necturus proximal tubule. J. Membr. Biol. 79:153-161.

33. Schultz, S. G. 1981. Homocellular regulatory mechanisms in sodium-transporting epithelia: avoidance of extinction by "flushthrough." Am. J. Physiol. 241:F579-F590.

34. Brooks, D. P., J. T. Crotton, L. Share, and A. Nasjletti. 1986. High potassium intake increases the plasma concentration and urinary excretion of vasopressin. Fed. Proc. 45:165. (Abstr.)

35. Reif, M. C., S. L. Troutman, and J. A. Schafer. 1986. Sodium transport by rat cortical collecting tubule. Effects of vasopressin and desoxycorticosterone. J. Clin. Invest. 77:1291-1298.

36. Wingo, C. S. 1985. Cortical collecting tubule potassium secretion: effect of amiloride, ouabain, and luminal sodium concentration. Kidney Int. 27:886-891. 